\title{
Poster 2014: A survey of respiratory physicians' opinion of SIT in asthma treatment in Wuhan of China
}

\author{
Rongfei Zhu*, Nan Huang, Guanghui Liu \\ From 2013 WAO Symposium on Immunotherapy and Biologics \\ Chicago, IL, USA. 13-14 December 2013
}

\section{Background}

Specific Immunotherapy has been applicated in allergic asthma for many years, however, in China, it's indication for asthma is still under controversial. The aim of our study is to investigate the respiratory physicians' opinion World Allergy Organization Journal 2014 7(Suppl 1):P25.

\section{Methods}

A 10-item questionnaire was designed in our study, the data were collected by telephone interview.

\section{Results}

252 respiratory physicians were enrolled and 224 effective questionnaire were included in analysis. Among the 224 physicians, $92.9 \%$ had heard of SIT before and $75.9 \%$ regard SIT as an effective treatment in allergic diseases. However, only $55.8 \%$ thought SIT was proved to be effective in asthma.43.8\% of the physicians agreed with that SIT had a long-term efficacy, $23.7 \%$ knew that there were two ways to perform SIT in clinic practice. But only $6.3 \%$ had prescribed SIT in their practice.

\section{Conclusions}

More than $50 \%$ of the respiratory physicians in Wuhan have a positive attitude to SIT and it's application in asthma treatment. However SIT is not widely used in asthma patients and the efficacy is still under controversial in physicians of Wuhan.

Submit your next manuscript to BioMed Central and take full advantage of:

- Convenient online submission

- Thorough peer review

- No space constraints or color figure charges

- Immediate publication on acceptance

- Inclusion in PubMed, CAS, Scopus and Google Scholar

- Research which is freely available for redistribution 